NBER WORKING PAPER SERIES

\title{
DO HISTORICALLY BLACK INSTTTUTTONS \\ OF HIGHER EDUCATION CONFER \\ UNIQUE ADVANTAGES ON BLACK STUDENTS: \\ AN INTTIAL ANALYSIS
}

Ronald G. Ehrenberg

Donna S. Rothstein

Working Paper No. 4356

\section{NATIONAL BUREAU OF ECONOMIC RESEARCH 1050 Massachusetts Avenue \\ Cambridge, MA 02138 \\ May 1993}

Irving M. Ives Professor of Industrial and Labor Relations and Economics at Comell University and Research Associate at the National Bureau of Economic Research, and Ph.D. candidate at Comell University. We are grateful to Dan Goldhaber and Michael Schultheis for their research and to Alan Fechter and his staff at the Watilliam H. Donner Foundations for financial suppor, used in section Ill of the paper. The vational Research Council for providing us with the data represent the views of Cornell University, the Nexped here are solely our own and do not foundation, or the National Research Council the National Bureau of Economic Research, either in Labor Studies. Any opinions expressed are This paper is part of NBER's research program Bureau of Economic Research. 
Working Paper \#4356

May 1993

\title{
DO HISTORICALLY BLACK INSTTTUTIONS \\ OF HIGHER EDUCATION CONFER \\ UNIQUE ADVANTAGES ON BLACK STUDENTS: \\ AN INITIAL ANALYSIS
}

\begin{abstract}
Do Historically Black Institutions (HBIs) of Higher Education confer unique advantages on black students? Our paper consists of two separate analyses that begin to address this issue.

The first uses data from the National Longitudinal Study of the High School Class of 1972 to ascertain whether black college students who attended HBIs in the early 1970s had higher graduation rates, improved early career labor market success and higher probabilities of going on to graduate or professional schools than their counterparts who attended other institutions. The econometric methods we employ control for the characteristics of the students, characteristics of the institutions, and the process by which black students decided to enroll (or were prevented from enrolling) in different types of institutions. We find that attendance at an HBI substantially enhanced the probability that a black student received a bachelor's degree within seven years, however it had no apparent affect on the student's early career labor market success and probability of enrolling in post-college schooling.

The second uses data from the 1987 to 1991 waves of the National Research Council's Survey of Earned Doctorates to provide evidence on the patterns of black citizen doctorates with respect to their undergraduate institutions. their graduate institutions, and whether they achieved academic positions in major American liberal arts and research/doctoralc institutions. Among the major findings is that black doctorates who received their undergraduate degrees at HBIs were much less likely to have received their graduate degree at a major research institution than those black doctorates who attended a major research or sclective liberal arts undergraduate institution. Similarly, among the black doctorates who entered academic careers, those with graduate degrees from HBIs were less likely to be employed in major American research or liberal arts institutions than those who received their graduate degrees from major research institutions.
\end{abstract}

Ronald G. Ehrenberg

ILR-Comell University

Ithaca, NY 14853-3901

(607) 255.3026

and NBER
Donna S. Rothstein

ILR-Cornell University

Ithaca, NY 14853-3901

(607) $255-3026$ 


\section{Introduction}

Throughout most of the late nineteenth and early twentieth century the majority of black American citizens lived and were educated in the south. They were formally excluded from southern segregated white institutions of higher education and found higher educational opportunities only in the Historically Black Institutions (HBIs) of higher education. 'Some of the latter (for example, Morehouse, Spellman and Fisk) were private institutions that were initially established by church-related organizations. Others (for example, Florida A \& M, Grambling and Morgan State) were public institutions established in the southern states after the Civil War to provide separate education for black youths. In the absence of allowing blacks to attend the same institutions as whites, the establishment of the public HBIs was necessary if the southern states were to meet the requirements of the second (1890) Morrill Act. As part of providing funding for land grant institutions, the Act required that the states provide educational opportunities for all of their citizens.

As the black population began to move to the north in response to urban industrial employment opportunities, the relative importance of the HBIs for the education of black college age students began to decline. The famous 1954 Brown v, Board of Education Supreme Court decision, which outlawed separate but equal public schools, actually had very little impact on many of the southern states and formally segregated higher educational systems remained. When integrated at all, the white institutions often did so only as a result of suits pursued by the NAACP in the courts. ${ }^{2}$ It was not until the passage of the 1964 Civil Rights Act, Title VI of which prohibited the allocation of federal funds to segregated public educational institutions, that any real progress at integration was made. However, this progress was very slow and in a 1973 Supreme Court decision, Adams v. Richardson, 
the southern states were formally finally ordered to dismantle their dual higher educational systems.

As recently as 1964, over half of all bachelor's degrees granted to black Americans were granted by HBIs. By 1973, with the continued black migration to the north and the beginnings of integrated higher education in the south, the HBI share had fallen to about one-quarter to one-third, a range in which it remains today. The 106 institutions officially classified as HBIs that exist today are listed in Table 1. Over 90 percent of the institutions are 4-year institutions and over 95 percent of the students enrolled in HBIs attend 4-year institutions. While more HBIs are private than public, the former are often quite small and about three-quarters of the students at HBIs are enrolled in public institutions. Approximately twenty percent of all black college students are now enrolled in the HBIs.

Despite the declining relative importance of the HBIs in the production of black bachelor's degrees, in recent years they have become the subject of intense public policy debate for two reasons. First, court cases have been filed in a number of southern states that assert that black students continue to be underrepresented at traditionally white public institutions, that discriminatory admissions criteria are used by these institutions to exclude black students (e.g., basing admissions only on test scores and not also on grades) and that per student funding levels, program availability and library facilities are substantially poorer at the public HBIs than at other public institutions in the state. ${ }^{3}$ In one 1992 case, United States v. Fordice, the Supreme Court ruled that Mississippi had not done enough to eliminate racial segregation in its state-run higher educational institutions." Rather than mandating a remedy, however, the court sent the case back to the lower courts for action. 
What should the appropriate action be? Should it be to integrate more fully both the historically white and historically black institutions by breaking down discriminatory admissions practices at the former and moving to (or newly establishing at) the latter some unique programs? Should the HBIs be eliminated and their campuses either folded into the historically white institutions or abandoned? Or should effort be directed at equalizing per student expenditure levels and facilities between campuses and not at worrying about the racial distribution of students at each campus, even if such policies might result in "voluntary separate but equal" institutions?

From an economic efficiency perspective, the appropriate policy responses will at least partially depend upon the answers to a number of questions. Do HBIs, per se, provide unique advantages to black students that they could not obtain at other institutions? If they do, do they do so because of the racial composition of their faculty or the racial composition of their students? If they do, would enrolling more black college students in higher expenditure/pupil integrated institutions actually leave these students worse off?

There is a long literature that stresses the importance of HBIs to black students, especially those from poorer socioeconomic and academic backgrounds.s This literature suggests that students at HBIs are likely to have better self-images, be psychologically and socially more well-adjusted, and to have higher grades than their counterparts at other institutions. Although it is asserted that HBIs graduate a larger proportion of the black students that enroll in them than do other institutions, only a much smaller number of studies have addressed (with mixed findings) whether HBIs continue to appear to enhance black student degree probabilities once one controls for differences in the characteristics of 
the students that attend HBIs and other institutions. Only a handful have addressed whether attendance at an HBI, per se, enhances black students' subsequent labor market and educational success; these studies typically find that they do not. None of these studies takes account of the process by which black students decide to enroll (or are prevented from enrolling) in different types of institutions.

To shed some light on these issues, the next section presents econometric analyses of whether black college students who attended HBIs in the early 1970s had higher graduation rates, higher early career labor market success and higher probabilities of attending graduate school, than their counterparts who attended other institutions. These analyses use data from the National Longitudinal Study of the High School Class of 1972 (NLS72). The econometric methods we emply control for characteristics of the students, characteristics of the institutions and the above mentioned matching process between students and institutions. ${ }^{6}$

The second subject of policy debate relates to the production and employment of black doctorates.' Despite vigorous (or nonvigorous?) affirmative action efforts, the proportion of faculty that is black at major American universities is typically quite low. In part, this reflects the small number of black doctorates that are produced annually, and many people stress the need to increase the production of black doctorates to overcome this problem. Projections of forthcoming overall shortages of doctorates also reemphasize the need to increase black doctorate production to help avert these shortages, independent of concerns about the need for black faculty to serve as role models for black students. 
What is the best way to increase the flow of black students into doctoral programs? Do HBIs currently serve disproportionately as the source of the black undergraduate students who go on for doctoral degrees? Should new doctoral programs be set up or existing programs strengthened at HBIs to enhance the flow of black doctorates? Or, should attempts be made to recruit more black students from HBIs, or more black students from other institutions, into existing doctoral programs at leading Research I institutions? In par, the appropriate policy responses depend on the answer to another question - do black undergraduate students from HBIs who go on to doctoral study and black students who get doctoral degrees at HBIs, do as well in the academic labor market as their counterparts from other institutions?

Section III provides partial answers to some of these questions using special tabulations prepared for us from the National Research Council's Survey of Eamed Doctorates. A brief concluding section summarizes the implications of our findings and suggests directions for future research.

\section{Did Historically Black Institutions of Higher Education Confer Unique Advantages on Black Students in the 1970s?}

This section presents a detailed description of our analyses of data on black college students from the National Longitudinal Survey of the High School Class of 1972 (NLS72). We focus on students who first enrolled in a 4-year HBI or other 4-year college within three years after their June 1972 graduation from high school. ${ }^{\mathrm{B}}$ Our interest is in learning whether attendance at an HBI per se increased the probability that these students received 
a bachelor's degree by 1979, improved their early (1979) labor market outcomes (as measured by earnings and an index of occupational prestige), and increased the probability that they subsequently enrolled in an advanced degree program?

These questions are all addressed in the context of models that permit the students' choice of college type (HBI or non-HBI) to be treated as endogenous. In places the models also control for the process that determined whether an individual was employed in 1979. The sensitivity of our findings to the statistical models used are stressed throughout.

\section{A) Descriptive Statistics}

Descriptive statistics for the 638 black students in our sample are found in Table 2; 298 , or 47 percent of these students, attended HBIs, while the remaining 340 students attended other institutions.

Mean SAT test scores (SAT) were substantially lower and high school ranks (HSRANK) were somewhat poorer for the students at HBIs. These students also tended to come from families with lower incomes (PARINC) and their parents were slightly less likely to have earned bachelor's degrees (DADBA, MOMBA). Not surprisingly, they were much more likely to have gone to high school in a state in the southeastem region of the country (SOUTH), where the majority of the HBIs are located. Indeed, the proportion of full-time equivalent undergraduates enrolled in HBIs (SLOTS) in the states in which students went to high school was typically twice as large for students who subsequently enrolled in HBIs than it was for students who did not subsequently enroll in HBIs.

Characteristics of the high schools that the students attended also differed between the two groups. Students enrolled in HBIs were more likely to have attended a public high 
school (PUBHS), to have greater proportions of black high school classmates (PBSHS) and black high school teachers (PBFHS), but were less likely to have gone to high school in an urban area (URBHS).

The characteristics of the colleges the students attended also differed. Mean SAT scores at the college or university in which the students enrolled (CSAT) were over 300 points lower in the HBI sample, while expenditures per full-time equivalent student (EXPST) averaged about 10 percent lower. The proportions of black students (PBSTU) and black faculty (PBFAC) at the students' institutions were both much higher in the $\mathrm{HBI}$ sample, and students at $\mathrm{HBIs}$ were more likely to be attending a private institution (PRIV).

Turning to some of the outcomes that will be of interest to us, the proportion of students that had received a bachelor's degree by the 1979 survey data (BA79) was .04 higher in the HBI sample. In contrast, average hourly earnings for the roughly 85 percent of both samples that were employed in 1979 (WAGE79) was almost 10 percent lower in the HBI sample. An index of employed individuals' occupational prestige (SE179) was also slightly lower at HBIs. ${ }^{10}$

One goal of our study was to estimate the effects of characteristics of colleges, other than whether they were HBIs, on students' educational and labor market outcomes. Of interest were questions such as; were outcomes higher at institutions that had greater expenditures/student and/or greater student test score selectivity? Were the advantages, if any, that can be attributed to HBIs due to the racial composition of the faculty or the 
racial composition of the students? Given that they historically have had different missions, did private HBIs benefit black students by more or less than public HBIs did?

Our ability to answer such questions is limited by the high correlations that existed among these college characteristics; these correlations are tabulated in Table 3. It is clear that in the pooled sample we could not hope to disentangle the effects of HBIs from the effects of other variables. Similarly, in the non-HBI sample, the high correlations between CSAT and EXPST and between PBSTU and PBFAC made it unlikely that we could estimate these variables' effects. Correlations are substantially lower in the HBI sample and hence, throughout the paper, we attempt to estimate the effects of the various institutional characteristics on the different outcomes attained by students enrolled in HBIs.

\section{B) The Decision to Attend an HBI}

Prior attempts to estimate whether attendance at HBls improve black students' graduation probabilities or labor market outcomes have, for the most part, treated whether a black student attended an HBI as exogenous." If students are not randomly assigned to HBIs, such a procedure may lead to biased coefficient estimates. As a first step, this section analyzes students' decisions to attend $\mathrm{HBls}$.

Given that a black student enrolled in a 4-year institution, what determines whether it was an HBI? The answer is a complex one because it depended not only on the student's preferences and resources, but also on the policies pursued by institutions. For example, a number of southern states have required scores on standardized tests that exceed a critical level as the sole criterion to gain admission to their historically white public institutions of higher education, in spite of the facts that black students often did poorly on these tests and 
that even the generators of the tests recommend that they not be used as the only criterion for admissions decisions. ${ }^{12}$

In the absence of being able to estimate a structural model in whicb we can identify both the admissions decision rules of all institutions and the preferences of each student, we adopt a simpler reduced form approach. A student's choice of institutional type, which resulted from his or her preferences and the constraints imposed by various institutions' decision rules, is assumed to have depended on the student's high school rank and SAT scores, characteristics of the student's family and the high school that be or she attended, and the characteristics of the HBIs and the other higher educational institutions in the state in which the student attended high school.

Why consider the characteristics of only institutions in a single state? It is well known that nationwide the vast majority of students attend college in the same state in wbich they went to high school. As Table 4 indicates, this was true in the 1970 s for students who attended HBIs as well. In 1976, 58 percent of the students enrolled in private HBIs and 84 percent of the students enrolled in public HBIs were in-state students. ${ }^{13}$ Since roughly three-quarters of all students in HBis attended public institutions, the overall instate percentage was around 78 .

Table 4 also contains a set of regression equations that seeks to explain the variation across HBIs in the proportion of freshmen that were in-state students. One key finding is that, holding the tuition level for out-of-state students constant, the lower was the tuition level for in-state students, the higher was the proportion of in-state students. In addition, other variables held constant (including tuition), private HBIs tended to attract a greater 
proportion of in-state students, and more selective HBIs tended to attract a smaller proportion of in-state students. These findings suggest several state-level institutional variables that should have influenced whether in-state students enrolled in an $\mathrm{HBI}$ in the state and, as described below, we include several in the model.

Table 5 presents probit estimates of our model of the determinants of whether an individual in our sample attended an HBI. ${ }^{14}$ The only state level variable included in the analyses reported in column (1) is SLOTS, the proportion of full-time equivalent undergraduate students in the student's high school state that were enrolled in HBIs. ${ }^{\text {.s }}$ The specification reported in column (2) adds three additional measures. RELTU1 is the average (weighted by FTE enrollments) tuition in HBIs in the state relative to the weighted average tuition for other institutions in the state. RELFAC is the weighted average proportion of faculty in HBIs in the state that were black relative to the weighted average proportion of faculty in other institutions in the state that were black. Finally, RELSAT is the weighted average SAT score in HBIs in the state relative to the average weighted SAT scores of other institutions in the state. Our expectation is that these variables in turn should be negatively, positively, and positively related to the probability of enrollment in an HBI.

The estimates in Table 5 suggest that students with higher test scores were less likely to attend HBIs. Students from public high schools and high schools with a greater proportion of black teachers were more likely to attend HBIs. Males were more likely to attend HBIs than females. Finally, parents' educational backgrounds and income do not appear to have influenced whether students attended an HBI. 
The fraction of full-time equivalent undergraduate student slots in a state that were available in HBIs also mattered. While the other state level variables proved to be jointly significant when included in the model, individually only RELTUI approached statistical significance and its coefficient was positive. Higher levels of RELTUI may have signified increased relative quality of HBIs in a way not captured by SAT scores, and thus may have led to an increased probability of black students' enrollment in an $\mathrm{HBI}$.

\section{C) The Characteristics of the Colleges Students Altended}

Characteristics of colleges, other than whether they are HBIs, may influence a student's educational and early labor market outcomes. The quality of an institution, as measured by its expenditure per student, or the quality of its students, as measured by their average test scores have been shown to matter. ${ }^{16}$ Within the HBI sector, the proportions of students and faculty that were black varied considerably and if HBIs did prove to confer unique advantages on black students, it is important to learn whether it was the racial mix of the students and/or that of the faculty that was responsible. ${ }^{17}$ Finally, as noted in the introduction, private and public HBIs may have had differential impacts on students. Thus, in some specifications, we include each of these variables in the educational and labor market outcome equations that appear in subsequent sections.

Of course, the characteristics of institutions chosen by students are not random and it is of some interest to understand how individuals are matched to institutional characteristics. To the extent that these characteristics enter into outcome equations, and we want to estimate the difference in an outcome that an individual would have achieved in the two sectors, it is also necessary for us to be able to predict the values of the 
characteristics for each individual for the choice (HBI or non-HBI) not taken. ${ }^{18}$ For both of these reasons, we require estimates of the determinants of the characteristics of the institutions that the students attended.

Table 6 provides such estimates for individuals enrolled in HBIs and those individuals enrolled in other institutions. The characteristics analyzed are the average SAT score in the institution (CSAT), institutional expenditures per student (EXPST), the proportions of black faculty (PBFAC) and students (PBSTU), and whether the institution was private (PRIV). ${ }^{19}$ In each case, the characteristic was assumed to depend on the weighted mean value actoss institutions in the sector in the state in which the individual went to high school of the same characteristic, as well as a vector of characteristics of the individual, his or her family, and the high school that he or she attended.

Not surprisingly, given that most individuals remained in the same state for college, the mean values of the state/sector characteristics prove to be important predictors. In addition, more able students, as measured by higher test scores and lower class rank, enrolled in institutions with higher average test scores and higher expenditures/student. For students not enrolled in HBIs, an increase in their test scores also were associated with lower proportions of black students and black faculty in the institution that the students attended. For students enrolled in HBIs, an increase in the proportion of black teachers in their high school was associated with an increase in the proportion of black faculty in their college. Finally, if a student graduated from high school in a state that had no HBIs and he or she attended an HBI, other variables held constant, the student tended to be enrolled in an HBI with higher average test scores, expenditures per student, proportions of black 
faculty and black students, and probability of being private. These latter findings suggest some of the institutional characteristics that black families that sent their children out of state to HBIs were interested in obtaining.

D) Receipt of a Bachelor's Degree by 1979

The proportions of students who received bachelor's degrees by 1979 were .554 in the HBI and .515 in the non-HBI sample respectively (Table 2). What happens to the difference in these proportions once one controls for differences between the two groups in the characteristics of individuals and the schools they attended, as well as the process by which students enrolled in HBIs or other schools?

Table 7 presents probit estimates of the probability that a bachelor's degree was received by 1979. Equations were estimated for students who attended HBIs, students who attended other institutions, and the pooled sample. In the separate sample cases, specifications were reported in which the probability was assumed to have varied with measures of the individual's ability and family background, and then these variables plus the characteristics of the college the individual attended. The pooled analyses included a dichotomous variable for whether the individual attended an HBI and also specifications in which this variable was treated as endogenous. To accomplish the latter, instruments for the student's institutional type were obtained from the choice of sector equations reported in Table $5 .^{20}$

Tuming first to the estimates by sector, students whose high school class rank was lower (better) were more likely to have received a degree in both sectors. Higher SAT scores were associated with higher completion probabilities, but the relationship is 
statistically significant only for students who did not attend HBIs. Students from wealthier families, as measured by higher family income or higher father's occupational prestige, had higher completion probabilities, as did students from families where the mother had a bachelor's degree.

When one adds the set of institutional characteristics, they prove not to be statistically significant as a group in each sector, and individually no individual characteristic was statistically significant either. ${ }^{21}$ One can not infer from these results that increasing either institutional selectivity, expenditure per student or the proportions of students or faculty that were black, increased black students completion probabilities in either sector. Nor were private institutions associated with higher completion rates than public institutions.

Turning to the pooled analyses, the results in column (1a) clearly indicate that, bolding other factors constant, the probability that a bachelor's degree was received by 1979 was significantly higher if the student attended an HBI than if the student attended another instiution. Indeed, one can make use of the coefficient estimates from column (1a) and the values of the explanatory variables for each individual to compute bow much higher the probability would have been for each individual if he or she attended an HBI. ${ }^{22}$ When this is done, the mean value of these differentials is seen to be .090 and the standard deviation of the differentials only .015 . This is strong evidence that these black students' probability of receiving a bachelor's degree by 1979 was higher if they attended HBIs than if they attended other institutions. ${ }^{23}$

The estimates in column (1a) do not control for the fact that enrollment in an HBI was not a random occurrence. To do so, we compute instrumental variable estimates for 
the probability a student was enrolled in an HBI from each of the two enrollment models found in Table 5. We then reestimate the graduation probability model twice replacing the dichotomous $\mathrm{HBI}$ variable in turn by each of the instruments. The resulting estimates appear in columns 111 and 112 in the table.

The latter two sets of coefficients prove to be virtually identical. The coefficients of the HBI instrument in both cases are much larger than the original HBI coefficient found in column (1a). Indeed, when one computes the implied impacts of attending an HBI in these models, as described above, one finds that the mean probabilities of obtaining a bachelor's degree by 1979 were over .20 higher in each of these two models if the individual attended an HBI. That is, controlling for the endogeneity of whether these students attended an HBI substantially increased our estimate of the $\mathrm{HBI} /$ non-HBI probability of graduating by 1979 differential.

Given that we obtained virtually identical estimates when the two different instruments for attendance at HBIs were used, for simplicity, in the remainder of the paper we report results only for the instrument derived from the specification that excludes the relative characteristics from the enrollment equation (Table 5, column 1).

E) Early Career Earrings

Table 8 presents estimates of the logarithm of 1979 hourly earnings equations for individuals who initially were enrolled in HBIs, but who were employed in 1979 and not enrolled full-time in college. Missing from this sample then will be full-time undergraduate or graduate students and/or individuals who were unemployed or not in the labor force. 
Table 9 presents similar estimates for individuals who were initially enrolled in other institutions.

Equations were estimated that both excluded and included whether the individual had received a bachelor's degree by 1979 . For each of these cases, since enrollment in an HBI was nonrandom, specifications were also estimated that controlled for the factors that determined whether an individual enrolled in an $\mathrm{HBI}$, using the sample selection bias correction method suggested by Heckman (1979). ${ }^{24}$ As is well known, this involves computing, and then adding, an estimated correction factor (the inverse Mills' ratio) to the model and then reestimating the models.

Since being employed in 1979 was also a nonrandom event, specifications were also estimated that controlled for the probability that each individual was observed employed. These latter specifications made use of estimated employment status equations and were estimated under the assumption that the correction factors for attendance at an HBI and being employed in 1979 were independent of each other. ${ }^{25}$

The explanatory variables included in these models were personal and family characteristics of the individual, the area unemployment rate in 1979 and, to control for price differences across areas, a vector of regional dichotomous variables and a dichotomous variable that indicates whether the individual attended an urban high school. The high school urbanization variable served as a proxy for the extent of urbanization in the area in which the individual resided in 1979 . Some specifications also included the characteristics of the college that the student attended. However, in neither sector did any of these college characteristics appear to significantly influence early career wages. 
Our interest in these equations is primarily so we can compute estimates from them as to whether individuals who attended HBIs earned more than they would have earned if they had attended other institutions. We make such estimates in a later subsection. For now, we note only two findings. First, the return to earning a bachelor's degree by 1979 was higher for individuals who attended HBIs than for other individuals (more on this below). Second, correction for both types of sample selection bias appear important for individuals who did not attend HBIs, and correction for selection bias associated with employment status appears important for individuals who attended HBIs.

Table 10 presents estimates of wage equations when the data for individuals who attended both HBIs and other institutions were pooled together and a dichotomous variable for attendance at an HBI added to the model. The -.021 coefficient of this variable in column (1), which is statistically insignificantly different from zero, suggests that enrollment in an HBI did not lead to an increase in early career earnings for black college students in the sample. This conclusion continues to hold when the sample selection bias correction method is used to control for being employed (column (1a)), when enrollment at an HBI is treated as endogenous and an instrumental variable estimate used instead of the actual value (column (1b)), and when the instrumental variable and the sample selection bias correction method are used simultaneously (column (1c)). That is, we find no evidence that attendance at an HBI led, on average, to increased 1979 hourly earnings. 20

What if we add whether an individual received a bachelor's degree by 1979 to the model, treat the degree attainment and wage equations as recursive and estimate the augmented wage equation? The coefficient of $\mathrm{HBl}$ becomes. .036 , and remains statistically 
insignificant. However, attainment of a bachelor's degree raises the logarithm of earnings by a statistically significant .214. Since individuals who attended HBIs were more likely to graduate, one may ask whether this positive indirect effect of HBIs on earnings was larger than the negative direct effect of attendance at an HBI.

The answer is no! The analogous (single equation) estimate of the marginal impact of attending an HBI on degree attainment by 1979 was .090 and thus the total effect of attendance at an HBI on 1979 earnings is estimated in percentage terms to have been -.017 $((.214)(.090)-036)$. Similar findings occur (column (3c)), when we control for both the endogeneity of $\mathrm{HBI}$ and for sample selection (employment) bias. With attendance at $\mathrm{HBI}$ treated as endogenous, the estimated mean impact of attendance at an HBI on degree attainment we obtained was .215. Hence, the estimated total effect of attendance at an HBI on eamings in percentage terms was the direct effect $(-.131)$ plus the indirect effect $(.200)(.215)$ or -.088 .

Finally, column (3) reports the results of allowing the effects of attendance at an HBI on earnings to vary with whether the individual actually graduated by 1979 . The pattern of coefficients suggests that, holding other variables constant, individuals who had not graduated from HBIs earned less than individuals who had not graduated from other institutions. In contrast, other things held constant, graduates of HBIs earned more than graduates of other institutions. There may have been a larger payoff to attending an HBI, but only if the student succeeded in graduating. 


\section{F) Early Career Occupational Prestige}

Tables 11,12 , and 13 replicate the analyses of the previous three tables replacing the logarithm of hourly earnings by the index of occupational prestige in the occupation in which the individual was employed in 1979. The rationale for using this alternative variable is that individuals may trade off earnings early in their careers for training opportunities. Thus, occupational prestige may be a better measure of early career success than earnings.

The results obtained when this alternative success measure is used are very similar to the earnings results, although neither correction for sample selection bias due to the nonrandom nature of employment status nor for attendance at an $\mathrm{HBI}$ mattered bere. Once again, the analyses conducted with the pooled sample (Table 13) suggest that attendance at an HBI did not lead to an increase in black students' early career occupational success. ${ }^{27}$ G) Enrollment in Graduate Education

Historically, HBIs graduated many of the black Americans who went on to graduate and professional schools and who ultimately assumed professional positions in the black community. We discuss the role HBIs play in the production of black doctorates in the next section. Here we ask whether, conditional on having received a bachelor's degree by 1979 , was it the case that graduates of HBIs in our sample were more likely to have enrolled in a master's, doctoral, or professional degree program by 1979 ?

In the aggregate, 33 percent of the individuals who received a bachelor's degree by 1979 were enrolled in such programs by 1979 . The comparable percentages for graduates of HBIs was 27 and for graduates of other institutions 38 . These raw percentages, however, ignore differences in the two groups in students' academic ability or family backgrounds 
(e.g., income), both of which might influence their propensities to attend graduate or professional school.

Table 14 presents estimates of probit probability of enrollment in graduate programs by 1979 , conditional on having received a bachelor's degree, equations. ${ }^{23}$ The simplest model (column (1)) included measures of a student's academic ability at the time he or she graduated from high school, the student's family background at that time, and whether the student attended an HBI. A student's academic ability and parents' income are seen to bave both positively influenced the probability of having been enrolled in postgraduate education, but attendance at an HBI per se did not significantly increase this probability. Use of an instrument for attendance at an $\mathrm{HBI}$, to control for its nonrandom nature (column (2)) did not change any of these findings.

When the data were stratified by whether the students attended an $\mathrm{HBI}$, the characteristics of the institutions the students attended can be entered into the models. This is done is columns (4) (non-HBIs) and (6) (HBIs). In each case, an increase in the proportion of black students in the institution's undergraduate student body is seen to bave been associated with an increase in the probability of enrollment in graduate education.

H) Did Allendance at an HBI Matter?

Table 15 compactly summarizes the predicted mean (across individuals) proportional differential impacts of enrollment in an $\mathrm{HBI}$ on the probability of having received a bachelor's degree by 1979, on hourly earnings (if employed) in 1979, and on the occupational prestige index (if employed) in 1979. 
In addition to the single equation (pooled sample) estimates that have already been discussed, estimates are presented for when separate "outcome equations" were estimated for individuals attending HBIs and other institutions. In these latter cases, estimates of mean differentials are reported for individuals initially in each sector. In addition, to ascertain the sensitivity of the findings to the statistical model used, estimates are reported for models in which attendance at an HBI was treated as exogenous, attendance at an HBI was treated as endogenous, and (where relevant) being employed was treated as endogenous. In each case, the models used are those that excluded the vector of institutional characteristics and (for wages and occupational status) excluded receipt of a bachelor's degree by 1979 . In each case, the predicted impact was computed for each individual in the sample and then the mean of the individual responses reported. ${ }^{20}$

Table 15 makes clear that attendance at an HBI did substantially increase the probability that black students in the sample received a bachelor's degree by 1979 . Depending on the specific model and statistical method used, the mean probability was between 9 and 29 percent higher if a student attended an HBI. In contrast, the impact of attendance at an HBI on early career labor market success, as measured by 1979 earnings or occupational prestige, was much smaller. In many cases the estimates were negative, although given the statistical insignificance of the underlying coefficients, all of these impacts on early career labor market success are probably insignificantly different from zero.

How could HBIs have improved black students' graduation probabilities, but not improved their early career labor market success? At least two explanations come to mind. On the one hand, the quality of education received by black students may have been lower 
at $\mathrm{HBls}$ and graduation standards lower at the HBIs also lower. On the other hand, employers may have discriminated more against black graduates of HBIs than they did against black graduates of other institutions. ${ }^{30}$ The data we have used do not permit us to distinguish between these two explanations.

\section{The Production and Early Career Attainment of Black Citizen Doctorates}

Historically, HBIs have provided many of the black college graduates who have gone on to earn doctoral degrees in the United States. In recent years, approximately 40 percent of the new doctorates granted to black citizens have gone to individuals who have received their undergraduate degrees from HBIs, even though the HBls grant only about 30 percent of the bachelor's degrees received by black Americans. Thus, the HBls are asserteo to be an important component of the pipeline for the production of black doctorates. ${ }^{31}$

This section investigates the role of HBIs in the production of black doctorates, using special tabulations prepared for us by the National Research Council from the Survey of Earned Doctorates (SED). Each year when doctoral candidates submit their dissertations to their graduate schools and receive their degrees, they are asked to respond to the SED. Of primary interest to us here are their responses relating to their field of doctoral study, the institutions at which they received their undergraduate and graduate degrees, and their plans for future employment or study. Because of the small number of doctoral degrees granted to black citizens in any one year, most of the tabulations that follow are based on data from a recent five year period. 
Table 16 presents data on the share of black citizen doctorates granted by HBIs and the share that went to individuals who received their undergraduate degrees from HBIs, by field, over the 1987-1991 period. Focusing initially on the latter, in the aggregate the share of black citizen doctorates granted to individuals with undergraduate degrees from HBIs was 39. However, this aggregate figure masks considerable variation across fields. Over 47 percent of all black citizens doctorates during the period were granted in the field of education and the share of black education doctorates going to individuals with undergraduate degrees from HBIs was .48 . While the analogous shares for the professional fields, the life sciences, and the humanities were all greater than 3 , the shares in the physical sciences, engineering, social sciences, and psychology were less than 3. In these latter fields, at least, undergraduates from HBIs are not over represented among black citizen new doctorates.

Perhaps another way to convey this point is to tabulate the share of black citizen doctorates granted in various fields, by institutional type. This is done in Table 17, where the first column again indicates that about 47 percent of all black citizen doctorates during the 1987-91 period were in the field of education, while the comparable percentage for black citizen doctorates who graduated from undergraduate HBIs was .55. Indeed, the shares of black citizen doctorates in each of the science, engineering, social science, and humanity fields were lower for undergraduate degree holders from HBIs than they were for graduates from the other types undergraduate institutions.

Returning to Table 16, it also indicates that the share of black citizens doctorates granted by HBIs was .09 during the period. The number of HBIs that grant doctorate 
degrees in any year is actually very small. For example, as Table 18 indicates, in 1991 there were eight such institutions and over two-thirds of the total number of degrees they granted were granted by Howard and Clark Atlanta University. If one excludes doctorates granted in education, the number of HBIs producing doctorates falls to four. The small number of doctorates produced annually by many of the doctoral programs in HBIs leads to the concern that these programs may be too small to reach the critical mass necessary to efficiently train doctoral students. ${ }^{32}$

What types of graduate institutions do graduates of HBIs attend for doctoral study and how do they compare to the institutional types that other black doctorates attend? This question is of some importance because, as we show below, where one attends graduate school heavily influences a new black doctorate's employment prospects. To answer this question, Table 19 presents cross-tabulations, by field, of black doctorates' undergraduate and graduate institutional types. The graduate institutions are broken down into HBIs, Research I doctorate granting institutions (the institutions that produce a large number of doctorates in a number of fields and whose doctoral programs often are highly rated), and other institutions. ${ }^{33}$ The undergraduate institutions are broken down into HBIs, Liberal Arts I (selective Liberal Arts) and Research I institutions, and other institutions.

In the aggregate, 9 percent of black doctorates during the 1987-91 period were granted by HBIs, 45 percent were granted by Research I Institutions and 47 percent were granted by other institutions. For those black doctorates whose undergraduate degrees were earned at HBIs, the comparable figures were 16,36 , and 47 percent respectively, while for black doctorates from Liberal Arts I and Research I undergraduate institutions, the figures 
were 5, 41 and 54 percent respectively. That is, black doctorates whose undergraduate degrees were earned at HBIs were much more likely to attend HBIs and somewhat less likely to attend Research I institutions for their doctoral study. Perusal of the field specific data suggests that the same pattern holds for each of the doctorate fields, although in some cases the differences are not as large as the overall ones.

Why do black doctorates who received their undergraduate degrees from HBIs tend to be less likely to wind up in elite Research I doctoral programs than graduates from Liberal Arts I and Research I institutions? In part, it may reflect differences in the ability levels and undergraduate training of students from HBIs vis-a-vis their counterparts from Research I and Liberal Arts institutions. In part, it may reflect their personal preferences to remain for graduate study in what they perceive to be a supportive environment. In part, it may reflect ignorance about the HBIs, discriminatory attitudes towards the graduates of HBIs, or the failure of faculty in the elite graduate programs to aggressively recruit potential graduate students from HBIs, most of which are located in different areas of the country than are the elite graduate programs.

The SED data do not permit one to distinguish between these various hypotheses. However, the fact that average test scores of black students tend to be lower at HBIs than at other institutions (see, for example, Table 2) and that over a recent seven year period only 20 percent of National Science Foundation Black Minority Graduate Fellowship winners received their undergraduate degrees at HBIs (Table 20), suggest that perceptions of differential ability or training are at least part of the problem. Indeed, 67 percent of 
these fellowship winners from HBIs came from four institutions and 45 percent came from Howard alone. The perceived quality of HBIs and their students may fall off quite rapidly.

The final information in the SED that is useful to us comes from the question that asks doctorates at the time their dissertation is approved, if they have already made definite employment plans? For those that have, additional questions are asked about whether academic or another form of employment, or a postdoctoral appointment, has been obtained. Finally, for those entering academic appointments, the name of the academic institution at which they will be employed is reported.

The tabulations reported in Table 21 indicate that, in the aggregate, 69 percent of all black citizen new doctorates during the 1987-1991 period had definite employment plans at the time that they received their degrees and that 58 percent of these had definite plans to work in academia or in postdoctoral positions. The comparable percentages are both higher for doctorates from Research I institutions than they are for doctorates from HBIs however, once one breaks the data down by field, a consistent pattern of results does not emerge across. That is, once one controls for field, on balance doctorates from HBIs are roughly equally likely to have definite plans at the time they receive their degrees and equally likely to have a postdoctoral or an academic position, as are doctorates from Research I institutions.

What is different, though, is the type of academic position doctorates receive if they do enter the academic sector. Table 22 provides data on the shares of black citizen new doctorates with definite plans in the academic sector that go on to employment in HBIs (including Howard), Research I or Liberal Arts I institutions, and other institutions. In the 
aggregate, these shares are $.23, .21$, and .56 , respectively. However, new doctorates from HBIs are much more likely to wind up in HBIs and much less likely to wind up in Research I or Liberal Arts institutions than are new doctorates from Research I institutions. ${ }^{34}$ Similarly new doctorates whose undergraduate degrees were from HBIs are much more likely to wind up employed in HBIs and much less likely to wind up employed and in Research I or Liberal Arts I institutions than are new doctorates whose undergraduate degrees came from Research I or Liberal Arts I institutions. ${ }^{35}$ Similar results hold for each of the seven specific fields for which data are tabulated in Table 22.

Again one can not ascertain if the sorting by institution type that occurs in these data are due to inherent differences in the ability or training of black doctorates who attended HBIs as undergraduate or doctoral students, vis-a-vis their counterparts at Research I or Liberal Arts I institutions, to lack of information about and effort to recruit students from the HBIs by the Liberal Arts I and Research I institutions, or to discriminatory preferences. If, however, a social goal is to increase the flow of talented black students into PhD programs and ultimately into academic positions in elite teaching and research institutions, a number of actions are possible.

First, one could increase the number and size of doctorate programs in HBIs. ${ }^{36}$ Second, one could more aggressively recruit graduates of HBIs into Research I institutions' doctoral programs and pursue extra efforts to retain these students until graduation. Third, one could more aggressively recruit black students who otherwise would attend HBIs to attend undergraduate programs at Research I or Liberal Arts I institutions. The third option is likely to have adverse effects on the "better" undergraduate HBIs and, without 
other policies, the first option appears likely to continue the current segmentation of black doctorate employment. Hence, building "pipelines" between the HBls undergraduate programs and the Research I institutions' doctoral programs appears to be the preferred strategy.

\section{Concluding Remarks}

What should public policy be towards the Historically Black Institutions of higher education? In an increasingly multicultural society, should public policy encourage their integration and/or incorporation into the larger and often better funded Historically White Institutions? Or should public policy facilitate the HBIs "specializing" in the education of blacks and other underrepresented minorities on American campuses, by providing the HBIs with improved facilities and increased annual support?

At the outset, it should be stressed that the only real question relates to the status of public HBIs. There is a long tradition in American private education of institutions being established by particular religious groups and then continuing to draw the majority of their students from members of these groups. No one objects to Catholics voluntarily attending Notre Dame or Georgetown, Mormons voluntarily attending Brigham Young, or Jews voluntarily attending Yeshiva or Brandeis. If voluntary association with predominately members of one's own group in a private nondiscriminating institution is deemed by an individual to be in his or her best interest, this choice should be permitted. Hence, no one should question the importance to black Americans of the private HBIs, those institutions 
that receive much of their support through private fund raising activities conducted by the United Negro College Fund.

What should public policy be towards the public HBIs? Our empirical analyses in section II focused on all HBIs as a group, however, we did not find that the public/private distinction was an important predictor of the benefits of attendance at an HBI. For black students attending college in the early 1970s, attendance at an HBI did substantially enhance their probability of receiving a bachelor's degree within seven years, however, it had no apparent effect on their early career labor market success and probability of enrolling in post-college graduate or professional schools. Furthermore, for none of these outcomes did it appear that attendance at an HBI yielded larger benefits for students from low-income families or students with low test scores than it did for other black students.

Of course, "early success" is not the same as "career success" and in future work we will examine if data from later waves of the NLS72 provide any evidence of larger gains for students who attended HBIs. ${ }^{37}$ In addition, to contemplate making policy recommendations for the 1990 s, up-to-date evidence is required on the effects of attendance at HBIs. Given that one needs data for at least seven to ten years after entrance to college to conduct any meaningful analyses, about the best one can do is to use data on students who entered college in the 1980 s. In subsequent work we will conduct such analyses using data from High School and Beyond (HSB), a national longitudinal survey of students who graduated from high school in 1980 and $1982^{38}$

Our analyses in section III of the National Research Council's Survey of Eamed Doctorates provided evidence on the patterns of black doctorates in recent years with 
respect to their undergraduate institutions, their graduate institutions, and whether they achieved academic positions in major American liberal arts and research/doctorate institutions. To the extent that one wishes to increase the flow of black doctorates to get more black Americans into faculty positions at major American colleges and universities, our tabulations suggest the need to increase the flow of black students into doctoral programs in major research institutions.

Of course, this presumes that hiring practices at American universities will remain the same and that perceptions of the quality of students at lesser programs, as well as the quality of training they receive, will remain unchanged. If federal funding for doctoral programs at HBIs could lead to high quality programs that attract high quality students, such funding may provide a viable option. Given the likely small scale of these programs and the complementary resources (e.g., libraries, faculty quality in other closely related fields) that they will have available (or unavailable) to them, one must question whether this option makes sense. Building better pipelines between the undergraduate HBIs and the Research I institutions' doctorate programs appears to be a preferred strategy. 


\section{References}

Allen, Walter. Gender and Campus Race Differences in Black Student Academic Performance, Racial Attitudes and College Satisfaction (Atlanta, GA: Southem Educational Foundation, March 1986).

Allen, Walter and John Wallace. "Black Students in Higher Education: Correlates of Access Adjustment and Achievement" (paper presented at the annual meeting of the Association for the Study of Higher Education, St. Louis, MO: November 1988).

Anderson, Ernest F. and Freeman A. Hoabowsk. "Graduate School Success of Black Students from White Colleges and Black Colleges", Joumal of Higher Education 47 (May/June 1977): 294-303.

Astin, A. Predicting Academic Performance in College (New York: The Free Press, 1971).

Astin, A. Preventing Students From Dropping Out (San Francisco: Jossey-Bass, 1978).

Ayres, Q. Whitfield. "Student Achievement at Predominantly White and Predominantly Black Universities, "American Educational Research Journal 20(2) (Summer 1983): 291-301.

Baratz, Joan C. and Myra Ficklen. "Participation of Recent Black College Graduates in Labor Market and Graduate Education" (Washington, DC: Educational Testing Service, 1983). 
Bowen, William G. and Neil L. Rudenstine. In Pursuit of the PhD (Princeton, NJ: Princeton University Press, 1992).

Chiro, Susan. "Ruling May Force Changes at Southern Universities", New York Times (June 27, 1992): 10.

Christy, Ralph D. and Lionel Williamson eds. A Century of Service (New Brunswick, NJ: Transaction Publishers, 1992).

Cross, $\mathrm{K}$ and H. Astin. "Factors Influencing Black Students' Persistence in College" in G. Thomas (Ed.), Black Students in Higher Education (Westport, CT: Greenwood Press, 1981).

Davis, James E. "Differential Academic Progression of Black Students at Historically Black Public and Private Colleges and Universities" (Cornell University, Ph.D. disser:ation, Ithaca, NY, 1988).

Ehrenberg, Ronald G. "The Flow of New Doctorates", Journal of Economic Literature 30 (June 1992): 830-875.

Featherman, D. and G. Stevens. "A Revised Socioeconomic Indicator of Occupational Status" in R. Hauser et. al. eds. Social Structure and Behavior (New York, Academic Press, 1982).

Fleming, Jacqueline. "Sex Differences in the Impact of College Environments on Black Students" in P. Perun (Ed.), The Undergraduate Woman: Issues in Educational Equity (Lexington, MA: D.C. Heath, 1982).

Fleming, Jacqueline. Blacks in College: A Comparative Study of Students' Success in Black and White Institutions (San Francisco: Jossey-Bass, 1984). 
Fleming, John E. "Blacks in Higher Education to 1954: A Historical Overview" in G. Thomas ed. Black Students in Higher Education: Conditions and Experiences in the 1970s (Westwood, CT: Greenwood Press, 1981).

Heckman, James. "Sample Bias as a Specification Error", Econometrica 47 (January 1979): $153-162$.

Hill, Susan T. The Traditionally Black Institutions of Higher Education: 1860 to 1982 (Washingtion, DC: National Center for Education Statistics, 1984).

Hoffman, Charlene M., et al. Historically Black Colleges and Universities, 1976-90 (Washington, DC: National Center for Education Statistics, 1992).

James, Estelle, et al. "College Quality and Future Earnings: Where Should You Send Your Children to College?," American Economic Association Papers and Proceedings 79 (May 1989): 247-252.

Johnson, Julie. "Are Black Colleges Worth Saving". Time (November 11, 1991): 81. 83.

Maddala, G. S. Limited-Dependent and Qualitative Variables in Econometrics New York: Cambridge University Press, 1983).

Mingle, James R. The Opening of White Colleges and Universities to Black Students" in G. Thomas ed. Black Students in Higher Education.

Pascarella, E., J. Smarh, S. Ethington and M. Nettles. The Influence of College on Self-Concept: A Reconsideration of Race and Gender Differentials," American Education Research Journal 24 (1987): 49-77. 
Pascarella, E., J. Smart and J. Stoecker. "College Race and the Early Status Attainment of Black Students," Journal of Higher Education 60 (1989): 82-107.

Pascarella, Ernst T. and Patrick T. Terenzini. How College Affects Students; Findings and Insights from 20 Years of Research (San Francisco: Jossey-Bass, 1991).

Peterson, M. et al. Black Students on White Campuses: The Impacts of Increased Black Enrollments (Ann Arbor: University of Michigan Institute for Social Research, 1979).

Rowan, Carl. Breaking Barriers: A Memoir (Boston: Little Brown, 1993).

Stoecker, J., E. Pascarella and L. Wolfe. "Persistence in Higher Education: A Nine Year Test of the Theoretical Model, "Journal of College Student Development 29 (1988): 196-209.

Thomas, Gail E. and Jomills H. Braddock II. Determining the College Destination of Black Students (Atlanta, GA: Southern Educational Foundation, 1981).

Thomas, G. 'College Characteristics and Black Students' Four-Year College Graduation," Journal of Negro Education 50 (1981): 328-345.

Thomas, G. and S. Gordon. Evaluating the Payoffs of College Investments for Black, White and Hispanic Students (Baltimore: Johns Hopkins University Center for Social Organizations of Schools, Report No. 344, 1985).

U.S. House of Representatives, Committee on Education and Labor, Hearing on Issues and Matters Pertaining to Historically Black Colleges and Universities (Washington, DC: U.S. Government Printing Office, 1991).

Willis, Robert J. and Sherwin Rosen. "Education and Self-Selection," Journal of Political Economy 87 (October 1979):S7-S36. 


\section{Footnotes.}

1. See Ralph D. Christy and Lionel Williamson (1992), John Fleming (1981), Susan Hill (1984), Charlene M. Hoffman, et al. (1992), and James R. Mingle (1981) for more complete discussions of the formation and history of HBIs.

2. Many of these are vividly described in Carl Rowen (1993).

3. See Julie Johnson (1991).

4. Susan Chira (1992).

5. See Pascarella and Terenzini (1991) for a summary of the literature. Noteworthy studies include Allen (1986), Allen and Wallace (1988), Anderson and Hoabowsk (1977), Astin (1978), Ayres (1983), Baratz and Finklen (1983), Cross and Astin (1981), Davis (1988), Jacqueline Fleming (1982, 1984), Pascarella, et al. (1981), Pascarella, Smart, and Stoecker (1989), Peterson, et al. (1979), Stoecker, et al. (1988), Thomas and Braddock (1981), Thomas (1981) and Thomas and Gordon (1985).

6. In later years, when black students became more common on white campuses, the effects of attendance at an HBI may have changed. As such, in future research we will present similar analyses for black students who entered college in the early 1980 s, using data from High School and Beyond.

7. See Ronald Ehrenberg (1992) for a discussion of these issues.

8. Over 95 percent of undergraduate enrollments in HBIs are in 4-year institutions. Hence, the restriction of the sample to students initially in four-year institutions is not a major one. Eighty-one percent of both the HBI and other college sample were first 
enrolled in September of 1972 and roughly 10 percent of each first enrolled in each of the next two years, so using a three-year "entrance window" should also not cause us any problems.

9. Data on the proportion of faculty at each American college and university that is black have been collected every few years since 1976 by the Equal Employment Opportunity Commission as part of their "Higher Education Staff Information" (EEO6). Citing confidentiality and budgetary restrictions, the EEO formally declined to provide us with data from the early years of the survey. Data for 1989 had been provided to the U.S. Department of Education and they kindly permitted us access to a version in which confidential data (earnings) had been removed.

The use of 1989 racial composition of the faculty data obviously provides us with an estimate of the racial composition of the faculty in the 1970 s that contains considerable measurement error. As such, this reduces our likelihood of observing that this variable significantly influenced the outcomes of black students.

10. The index of occupational prestige is the revised Duncan index and is found in D. Featherman and G. Steven (1982). The index is defined at the three-digit census occupation level and spans the range 14.3 to 87.4 in our sample. Prior research has established that this index is highly correlated with the national median earnings and median education levels of individuals employed in the occupation.

11. See, for example, Thomas and Gordon (1985), Cross and Astin (1981), Pascarella, Smart, Ethington and Nettles (1987), and Pascarella, Smart, and Stoecker (1989). 
12. See Scott Jaschik (1992).

13. As Table 4 also indicates, these percentages declined by 1988 . This mirrors a national trend in which, faced with a declining applicant pool, more and more institutions recruited their students from wider geographic markets.

14. An appendix that is available from the authors, spells out the formal statistical models used here and throughout the paper.

15. SLOTS is zero if no HBIs were present in the state.

16. For example, see Estelle James, et al. (1989).

17. For example, as indicated in Table 2, the standard deviations of the proportions of black students and black faculty at HBIs that students in the sample attended were .131 and .106 respectively.

18. See the appendix for a more complete description of this point.

19. For simplicity, we treat whether an individual enrolled in an HBI as given here. It could, as we do later in the paper, be made endogenous, or determined simultaneously with the other characteristics.

20. See G. S. Maddala (1983) for this dummy endogenous variable method. In future work, we will consider addressing the endogenous nature of sector choice in the context of the separate sector models using a bivariate probit model.

21. Recall the discussion above about the high correlation of these variables in the non-HBI sector.

22. See the appendix for details.

23. Similar calculations using the separate sample estimates, which we report below, yield similar findings. We note that in specifications not reported here we found no 
evidence that the effects of HBIs on bachelor's degree attainment were larger for students who had low test scores or came from low-income families.

24. See the appendix for details.

25. Again, see the appendix for details. The employment status equations included all of the variables that entered into the earnings equations, as well as variables reflecting the individual's marital status, number of children, and (if married) spouse's income, all in 1979. Each of these latter variables' effects were allowed to differ for men and women.

26. Furthermore, in specifications not reported here, we found no evidence that attendance at an HBI was associated with increased 1979 earnings for either low test score students or students from low-income families.

27. Again, as in the previous footnote, no unique gains were observed for students from low-income families or students with low test scores who attended HBIs.

28. Future drafts may experiment with correcting for sample selection bias due to the nonrandom nature of having received a bachelor's degree.

29. Again, see the appendix for details.

30. In addition, students in 1979 were no more than three years post-college graduation; labor market outcomes this early may not be good measures of their career labor market success. In future work we plan to use data from the 1986 wave of the NLS72 to address this issue.

31. See, for example, the statement of Congressman William Gray in U.S. House of Representatives (1991). 
32. See William Bowen and Neil Rudenstine (1992) for a discussion of the relative ineffectiveness of small doctoral programs.

33. Howard University is classified throughout this section as an $\mathrm{HBI}$, not as a Research I institution, which in fact, it also is.

34. The two percentages are respectively for doctorates from HBIs 58 and 4, and for doctorates from Research I institutions 18 and 31 .

35. Similarly, the two percentages are, respectively 41 and 14 , and 12 and 36 .

36. For example, some federal funding for selected graduate programs at $16 \mathrm{HBIs}$ in science, engineering, mathematics, and professional fields is provided in fields in which African Americans are underrepresented under Section 303 of PL102-325, the Higher Education Amendment of 1992.

37. The last wave of NLS72 was conducted in 1986. Unfortunately, the sample size was substantially reduced, which decreases the likelihood that we will be able to observe HBIs having any statistically significant effects then.

38. HSB initially surveyed students who were high school seniors and sophomores in 1980. The former were last resurveyed in 1986 (6 years after high school graduation) and the latter in 1990 (8 years after high school graduation). So again, at best one can focus on early career labor market and educational success with them. 
Thisk 1

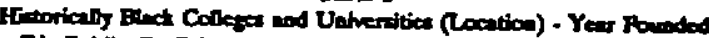

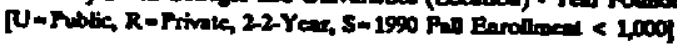

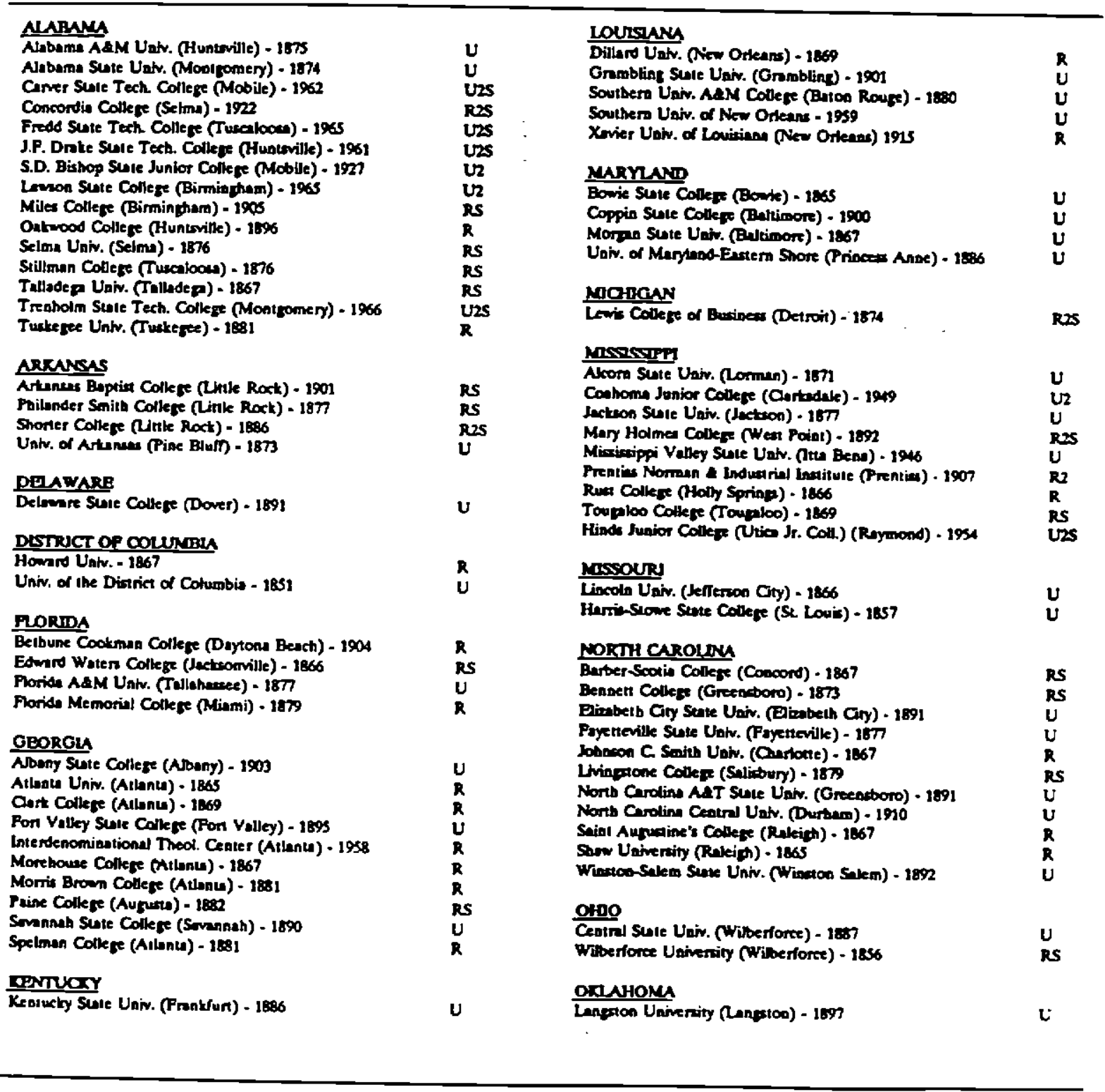


Tuble 1 (mootine)

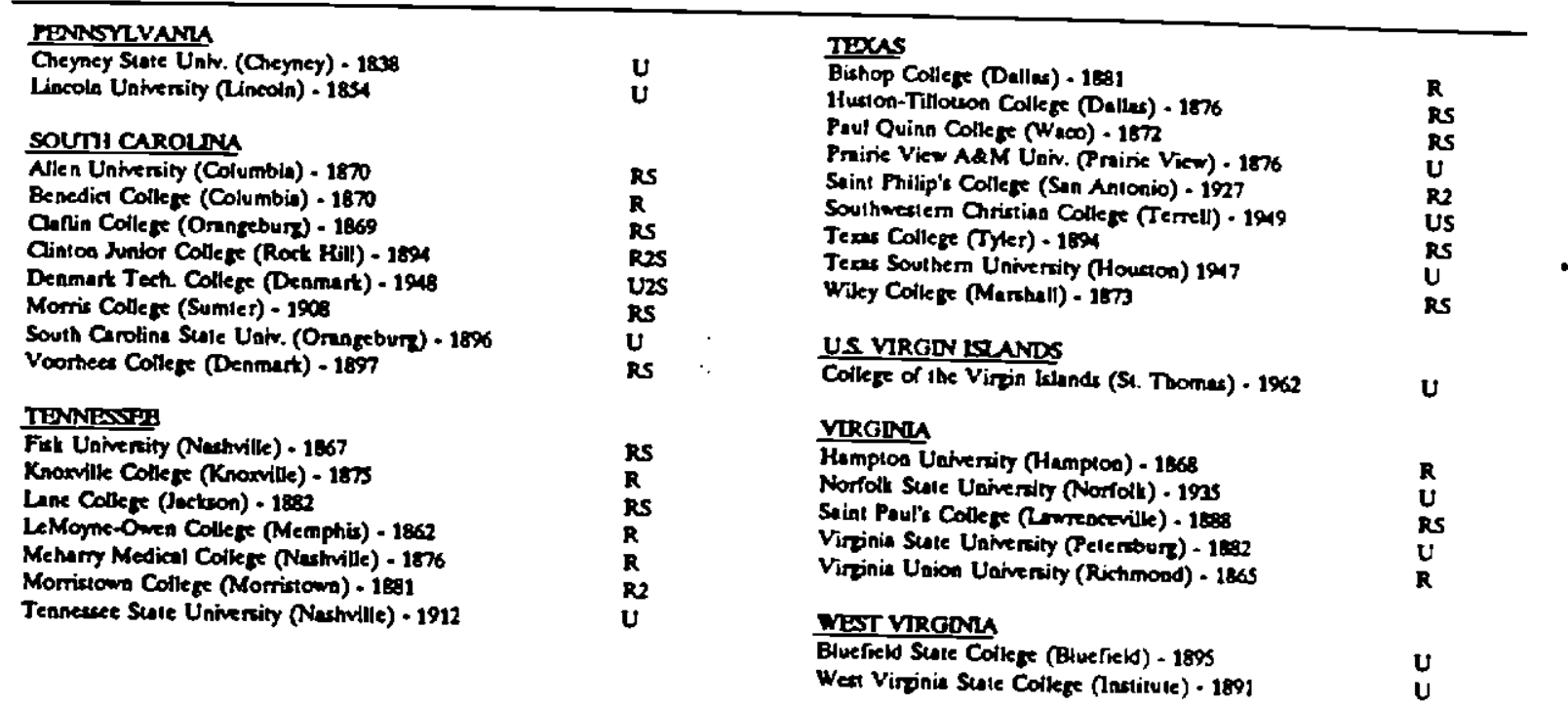

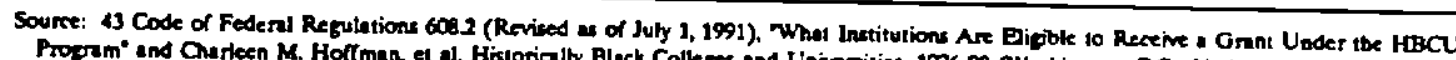

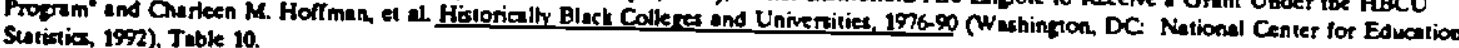


Table 2

Descriptive Statistles: NLS72 Sample

\begin{tabular}{|c|c|c|c|c|c|c|}
\hline \multirow[b]{2}{*}{ Verisble } & \multicolumn{3}{|c|}{ HB1 Sample } & \multicolumn{3}{|c|}{ Non-HBI Sample } \\
\hline & $\mathbf{N}$ & Meas & S.D. & $\mathbf{N}$ & Mean & S.D. \\
\hline SAT & 189 & 69.157 & 13264 & 237 & 26.024 & 16.186 \\
\hline HSRANK & 239 & .402 & 262 & 297 & 372 & 262 \\
\hline MALE & 298 & 399 & .491 & 340 & 368 & .483 \\
\hline PARINC & 233 & 70.990 & 51.048 & 273 & 80.745 & 54.023 \\
\hline DADBA & 294 & .092 & 289 & 335 & .099 & 298 \\
\hline MOMBA & 295 & .108 & 312 & 338 & .112 & 316 \\
\hline DADSEI & 243 & 30.432 & 18.359 & 289 & 29.904 & 18.273 \\
\hline PUBHS & 298 & .919 & 273 & 340 & 882 & 323 \\
\hline PESHS & 279 & .621 & 318 & 308 & .478 & 325 \\
\hline PBFHS & 279 & .400 & 253 & 308 & 235 & 213 \\
\hline COLL24 & 279 & .445 & 215 & 308 & .448 & 211 \\
\hline URBHS & 279 & 237 & .426 & 308 & 289 & .454 \\
\hline SLOTS & 298 & .127 & .077 & 340 & .060 & .078 \\
\hline SOUTH & 298 & .718 & .451 & 340 & 323 & .469 \\
\hline CSAT & 298 & 69.986 & 7.791 & 340 & 102.128 & 11.052 \\
\hline PBFAC & 255 & .617 & .131 & 317 & .037 & .043 \\
\hline PBSTU & 298 & .925 & .106 & 340 & .100 & .110 \\
\hline EXPST & 298 & 27,362 & 12.005 & 340 & 31.295 & 21209 \\
\hline PRIV & 298 & 332 & .472 & 340 & 274 & .446 \\
\hline WAGET9 & 253 & 5.807 & 3.047 & 288 & 6.298 & 4.076 \\
\hline SEI79 & 253 & 43.415 & 17.067 & 288 & 45.829 & 17.641 \\
\hline BA79 & 298 & 554 & .498 & 340 & 515 & 501 \\
\hline
\end{tabular}


Table 2(contlnued)

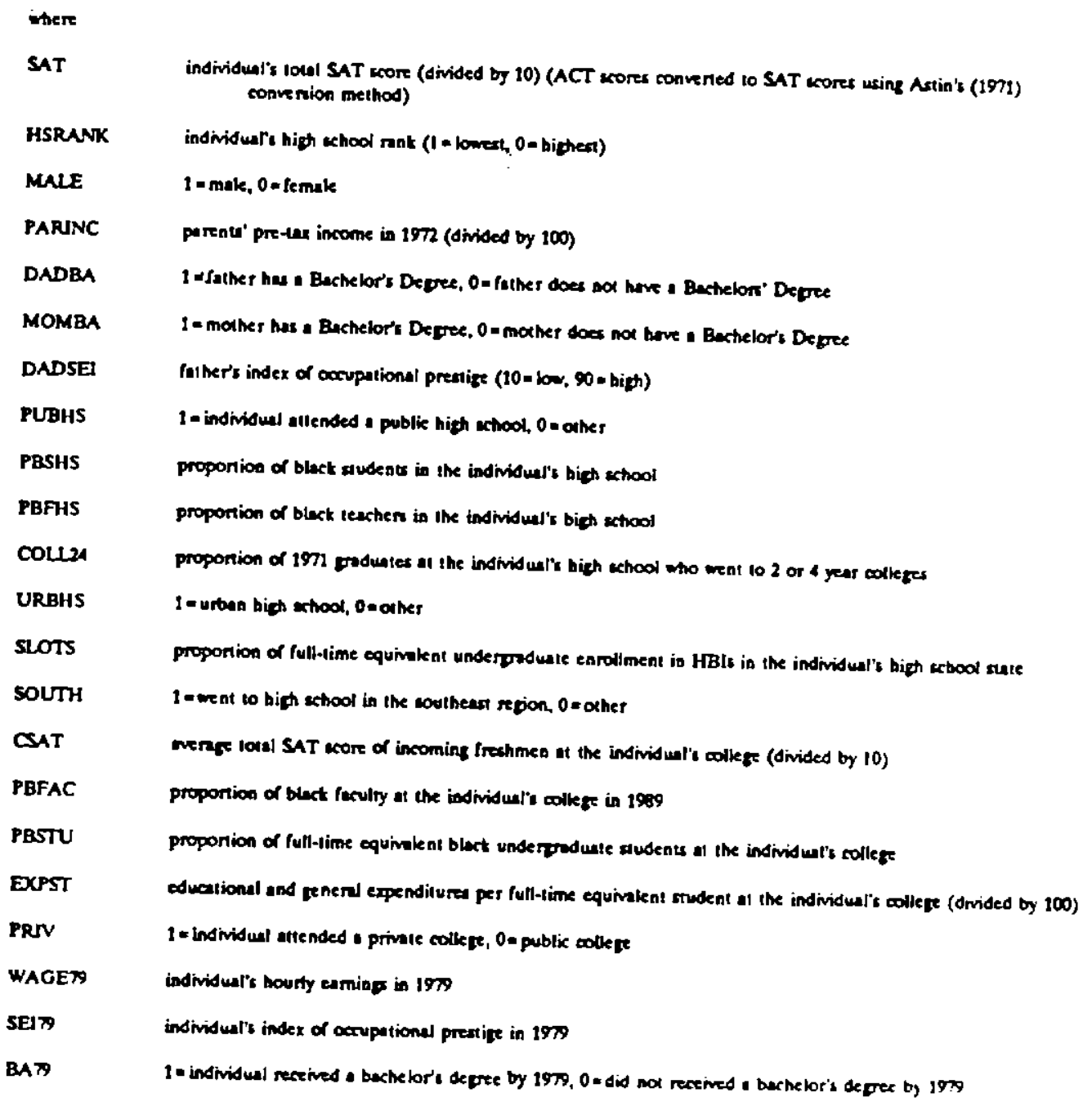


Table 3

College Characteristics Correlation Matrices

\begin{tabular}{|c|c|c|c|c|c|}
\hline \multirow[t]{2}{*}{$\begin{array}{c}\text { HBI } \\
\text { CSAT } \\
\text { EXXPST } \\
\text { PBSTU } \\
\text { PBFAC }\end{array}$} & 86 & $\begin{array}{c}-.11 \\
.40 \\
\vdots \\
\vdots\end{array}$ & $\begin{array}{l}.97 \\
. .86 \\
-.16\end{array}$ & $\begin{array}{r}95 \\
.83 \\
. .11 \\
.96\end{array}$ & $\begin{array}{l}.06 \\
.05 \\
.32 \\
.08 \\
.06\end{array}$ \\
\hline & CSAT & EXPST & PBSTU & PBFAC & PRIV \\
\hline \multirow[t]{2}{*}{$\begin{array}{c}\text { HBI }=0(n=340) \\
\text { CSAT } \\
\text { EXPST } \\
\text { PBSTU } \\
\text { PBFAC }\end{array}$} & .70 & $\begin{array}{l}-.17 \\
.29\end{array}$ & $\begin{array}{r}-.13 \\
-.17 \\
.56\end{array}$ & $\begin{array}{r}34 \\
30 \\
.00 \\
-.06\end{array}$ & \\
\hline & EXPST & PBSTU & PBFAC & PRIV & \\
\hline \multirow[t]{2}{*}{$\begin{array}{c}\text { HBI }-1(\pi=298 \\
\text { CSAT } \\
\text { EXPST } \\
\text { PBSTU } \\
\text { PBFAC }\end{array}$} & 33 & $\begin{array}{l}-.29 \\
-.25\end{array}$ & $\begin{array}{r}. .18 \\
. .04 \\
.14\end{array}$ & $\begin{array}{r}.00 \\
.43 \\
.14 \\
.01\end{array}$ & \\
\hline & EXPST & PBSTU & PBFAC & PRIV & \\
\hline
\end{tabular}

"All variables are defined in Table 2. 
Table 4

Delermionets of the Proportion of Preshoes of I Faorically

Bunt Inditutions Thet Were losule Siudeats

(aboolule vilue $t$ etalition)

\begin{tabular}{|c|c|c|c|c|c|c|c|c|}
\hline & \multicolumn{2}{|c|}{ (1) } & \multicolumn{2}{|c|}{ (2) } & \multicolumn{2}{|c|}{ (3) } & \multicolumn{2}{|c|}{ (4) } \\
\hline & (F) & (FB8) & $(F \times)$ & (Fes) & $(P \times)$ & (Fis) & $(F \times)$ & (FE) \\
\hline DNT & $.96 \times(16.8)$ & $2003(95)$ & .740 (3.7) & $M 7(23)$ & $.95 \times(185)$ & $.760(63)$ & $109(3.7)$ & $591(2.4)$ \\
\hline PRS & $\cos (1.0)$ & $219(1.9)$ & $0.04(0.7)$ & $220(20)$ & $.169(15)$ & $240(1.7)$ & . $153(1.4)$ & $217(1.7)$ \\
\hline Tume & $-.361(1.0)$ & $-.238(3.3)$ & $.314(2.8)$ & $.236(33)$ & $-.481(4.0)$ & $.255(28)$ & $-.461(3.6)$ & $-256(28)$ \\
\hline $\begin{array}{l}19 \text { Stale } \\
\text { Dummies } \\
\text { Induded }\end{array}$ & no & 10 & DO & $D$ & $y$ & 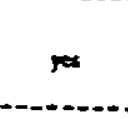 & $r$ & $9 x$ \\
\hline$\therefore$ & 8 & 9 & 6 & 9 & 89 & 9 & $\theta$ & 94 \\
\hline$R^{2}$ & 395 & A12 & 391 & A26 & 526 & 408 & $\$ 15$ & .458 \\
\hline
\end{tabular}

"Aleo included are dummy verisbles for sonreporting of ruition keves and is (2) and (4)). abrence of a melectivity nting. The

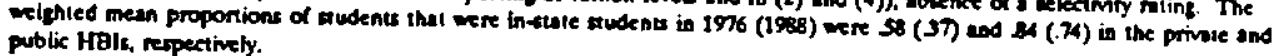

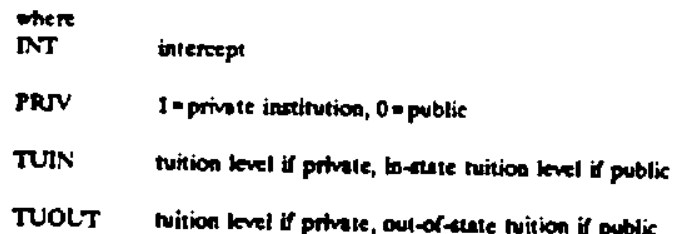

ThOLT

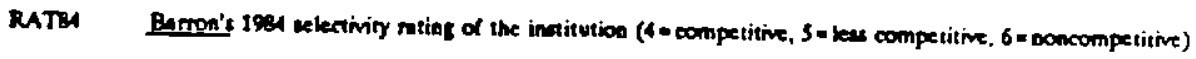

PSAME proportion of irshmen that ere in-atale apdents

Sourses:

1) Barron's Profile of American Colleses (Woodbury, NY: 1924) - RATM

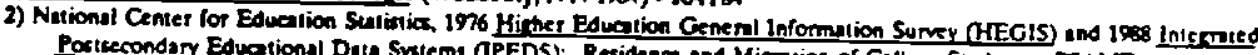
Poctcecondary Eduational Date Sytems (TPEDS): Residence end Miention of Colle re Studenu - PSAME

3) 1976 HEGIS and IPEDS Institutional OAdecteristic - PRV, TUIN, TUOUT 
Table 5

Probit Eatimales of use Decisios to Anead

- Iriatorican, Bact Collepo

(absolute vilue I mitios)

\begin{tabular}{|c|c|c|}
\hline & (1) & (2) \\
\hline sLor & $5.700(7.2)$ & 3841 (38) \\
\hline HSRANK & $310(1.2)$ & $m(1-1)$ \\
\hline PUBHS & $.434(23)$ & 34 (18) \\
\hline PBFHS & $1.020(23)$ & 1.016 (22) \\
\hline PBSHS & $216(0.7)$ & $217(0.7)$ \\
\hline $\operatorname{col} 124$ & $279(0.9)$ & $612(1.9)$ \\
\hline URBHS & $.120(0.9)$ & 200 (12) \\
\hline SAT & $.017(3.4)$ & -.018 (3.4) \\
\hline SATD & $-1.174(3.1)$ & .1 .248 (3.2) \\
\hline MALE & $2002(1.7)$ & 201 (1.7) \\
\hline MOMBA & $0.014(0.1)$ & $.0 m(0.4)$ \\
\hline DADBA & $.049(0.2)$ & (111 (0.5) \\
\hline DADSE & $.000(1.2)$ & .001 (1.4) \\
\hline PARINC & $-.001(0.4)$ & $.000(0.1)$ \\
\hline REITI & & $497(1.9)$ \\
\hline RELFAC & & $\cos (12)$ \\
\hline RELSAT & & $.738(0.6)$ \\
\hline$x^{2} / D O F$ & $170.142(20)$ & 197306 (25) \\
\hline $\mathbf{N}$ & 638 & 638 \\
\hline
\end{tabular}

- Ales inctuded in the equation are diethotomour varibbles for nonreponing of bigh echool mant.

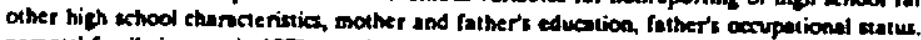

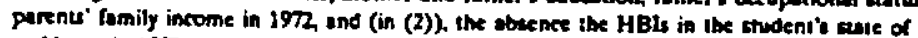
residence in 1972 and the absence of dats on blact faculty in thate that hes al leas one HBI.

Where

SAT

indinidual's lowl SAT wore (ACT seores comened to SAT cole) if reported, 0 - SAT not reported

SATD

I- SAT nol reponed, 0-SAT reponed

RELII

menge (weighied by FIE enroltments) tuition in HBI's in the mude ni's bien whool atele relative to overase (exigtied) tuition in ofler inatilutions in the atete

RELFAC

werege (exighied) proponion of blact faculty in HBC's in the stale relative 10 the menge (exighied) proportion of blact forvity in oxter inseitutions in the wole

REISAT

menge (weifhled) SAT score of HBis in the ate relotine to the menge (weighied) SAT wore of other institutions in the atele

Al other vorisbles ore defined in Toble 2 


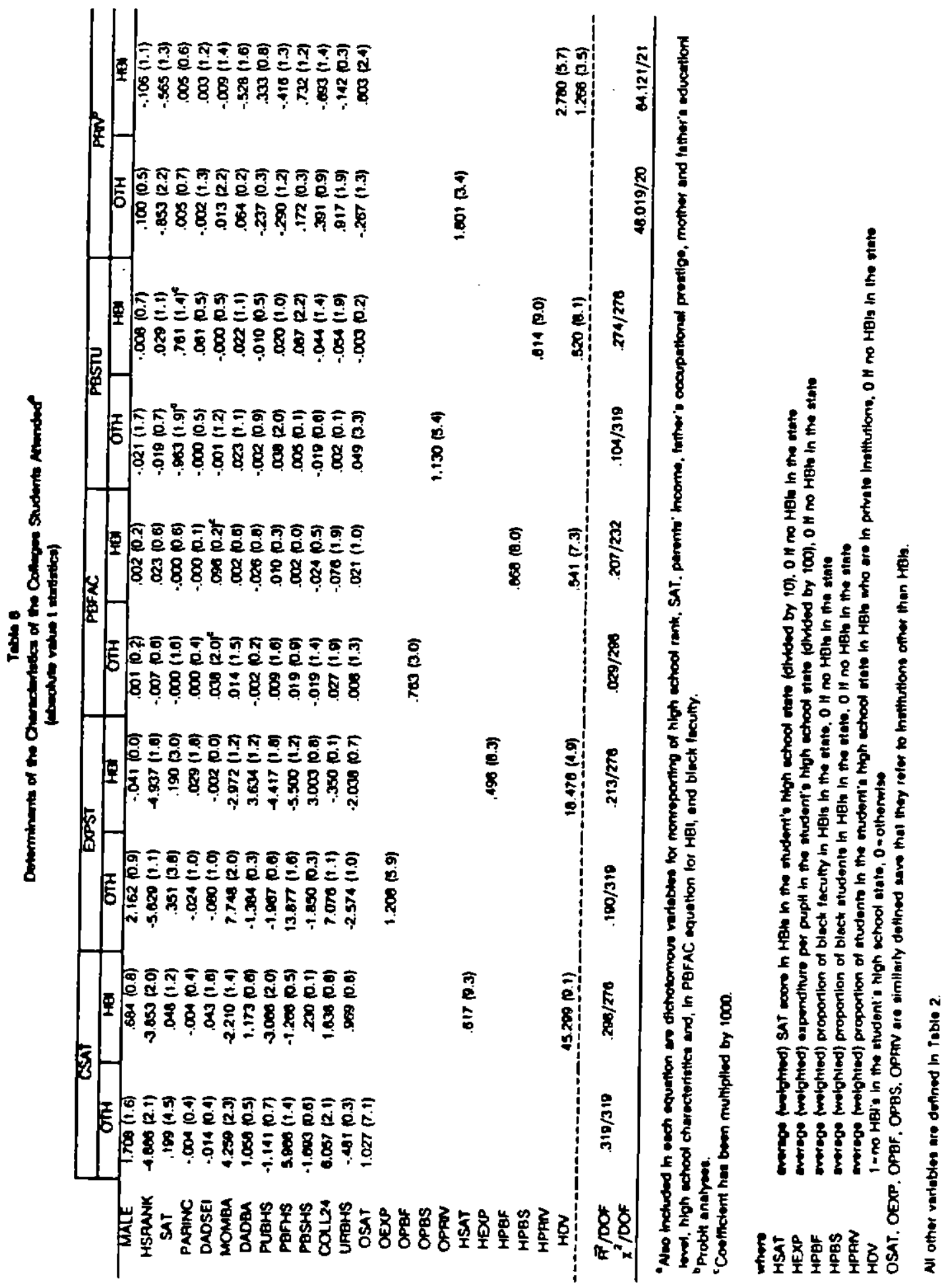




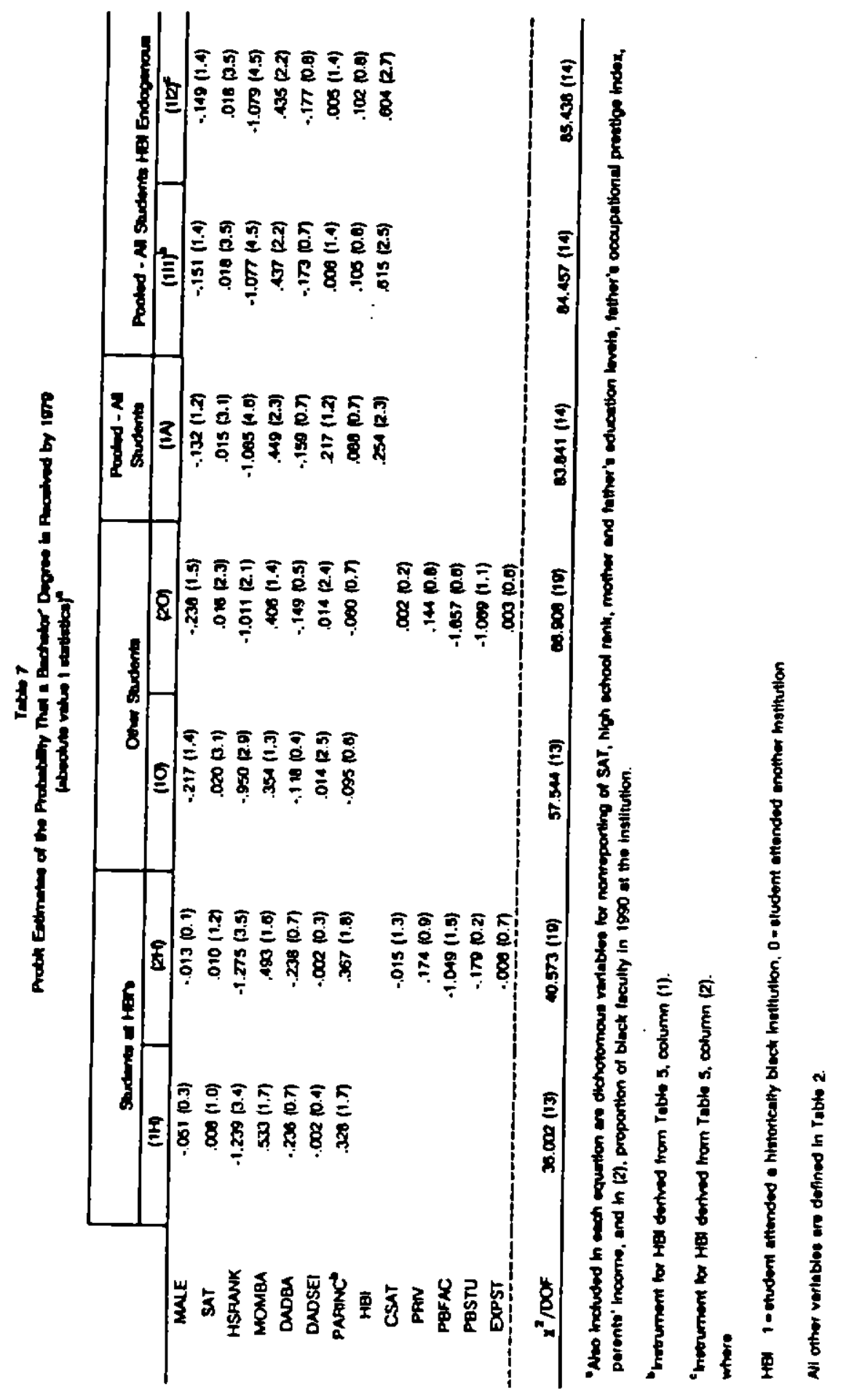

